\author{
Nina SHTOK \\ Lingwistyczna Szkoła Wyższa w Warszawie \\ n.shtok@wykladowca.lingwistyka.edu.pl \\ http://orcid.org/0000-0003-1333-0140
}

\title{
COGNITIVE LINGUISTICS - A HISTORICAL CONTEXT
}

The article offers a brief overview of the most prominent landmarks in the development of Cognitive Linguistics. It starts with the very inception of the field in the late 70s as a strong reaction against the doctrine dominating at that time of generative linguistics. Later the paper describes the cornerstone theories which were at the onset of this linguistic enterprise. From the very beginning the movement was rather diverse and still cannot be defined as one unified theory. But there has always been one commonality in its approaches, which is the centrality of meaning in language study. The works of the second wave of cognitive linguists, which are also outlined in the article, focused even more increasingly on the cognitive functions providing insight into the nature and organization of human thoughts. Nowadays the postulates of Cognitive Linguistics are applied not only to all levels of language study but extended to other scientific areas.

Cognitive Linguistics is a modern field of linguistic studies with "a long past and a short history" (Nerlich B, David D. C.: 2001). The long past of Cognitive Linguistics overlaps with psychology, philosophy, and the cognitive sciences, emerging as a new approach to language with its principles, assumptions, perspectives, and diverse range of theories.

The inception of Cognitive Linguistics as a separate field of study goes back to the late 1970s and 1980s. A notable event in the founding of the approach was the creation of the International Cognitive Linguistic Society in 1989, followed shortly by the journal "Cognitive Linguistics" 
(Mouton de Gruyter) in 1990 and the first conference of the International Cognitive Linguistics Association (ICLA) in Germany (1989).

From its very beginning the movement was rather diverse and still cannot be characterized by a theoretical unity in its assumptions and commitments. In this sense, Cognitive Linguistics is a flexible framework rather than a single theory of language, constituting a cluster of many partially overlapping approaches (Lewandowska-Tomaszczyk: 2007). Nonetheless, a unifying theme was an underlying consensus of dissatisfaction with the ideas dominating the twentieth-century linguistic doctrine of the generative approach to language, which set the stage for a new course in linguistics.

The Generative approach to linguistics viewed language as an internalized system of rules (Chomsky: 2006) where knowledge of a language was based on correct grammar construction ("...formulating the necessary and sufficient conditions that a system must meet to qualify as a potential human language...") with the central objective being a well-formed sentence. Thus, the major principles of Generative Grammar relied on the prevailing role of syntax, disregarding in many aspects the roles of semantics, pragmatics, and the conceptual links between syntax and semantics in linguistic theorizing.

For many, such a vision of language was unacceptable, casting questions and doubts on the principle assumptions of the generative linguistic approach. The first glimpses of dissatisfaction became obvious as early as the mid-1970s when George Lakoff abandoned his attempts to pursue Generative Semantics, which was aimed at converging the ideas of Chomsky's transformational Grammar and formal logic. In his interview with Brockman, Lakoff points out, "Noam claimed then - and still does, so far as I can tell - that syntax is independent of meaning, context, background knowledge, memory, cognitive processing, communicative intent, and every aspect of the body. In working through the details of his early theory, I found quite a few cases where semantics, context, and other such factors entered into rules governing the syntactic occurrences of phrases and morphemes." (Lakoff: 2000).

As we can see, one of the basic aspects distinguishing Cognitive Linguistics from Generative Grammar since its inception has been the central role of 'meaning' in the theory. As, for example, Ronald W. Langacker stated, "Meaning is what language is all about; the analyst who ignores it to concentrate solely on matters of form severely impoverishes the nat- 
ural and necessary subject matter of the discipline and ultimately distorts the character of the phenomena described (Langacker: 1987).

But of course, this linguistic endeavour from the very beginning went far beyond the shallow self-perception of merely being non-generative. It united the linguists in developing their approaches to language and linguistic theory, with a particular focus on cognitive principles and concerns. They addressed the basic conceptual structures behind the meaning that a conceptual system language is thought to reflect, such as structuring categories of different degrees of complexity, language grammar as a reflection of cognitive abilities, conceptual integration, and many others.

Charles Fillmore's theory of Frame Semantics was the first to conjoin these aspects into a singular theory. He began work on his model of conceptual structures in the 1970s, developing one of the most influential theories in Cognitive Linguistics. Fillmore describes his Frame Semantics as "a model of the semantics of understanding: the full, rich understanding that a speaker intends to convey in a text and that a hearer constructs for the text." (Fillmore 1985:235). Fillmore's approach (1975, 1977, 1982, 1985; Fillmore and Atkins: 1992), attempts to unveil the properties of the structured inventory of knowledge associated with words. The central notion in this approach is a knowledge structure evoked by words - the frame. It should be mentioned that the notion of the frame had been explored in other fields of study before it was introduced into Cognitive Linguistics (psychology, artificial intelligence). Fillmore applied this term for the purpose of linguistic description only, claiming that "the general word frame can be used for specific unified frameworks of knowledge, or coherent schematization of experience. Such a frame represents the particular organization of knowledge which stands as a prerequisite to our ability to understand the meanings of the associated words" (Fillmore 1985: 223).

As mentioned above, the focus of the Cognitive Linguistics enterprise is on meaning. Fillmore's theory of semantic frames embraces an encyclopaedic view of meaning, which is another significant contribution, and undoubtedly, a pillar of the language study within this approach. Fillmore rejected conventional dictionary meanings as an insufficient schematic model of knowledge. Encyclopaedic knowledge, by contrast, "gives an account of knowledge structures in describing the semantic contribution of individual lexical items and grammatical constructions and in explaining the process of constructing the interpretation of a text" (Fillmore 1985: 233). 
Fillmore's Frame Semantics was closely connected to other advances in Cognitive Linguistics as the field was developing. Here we can mention the theory of prototypes (Rosch: 1973), Lakoff's cognitive models (1983), Langacker's theory of domains, the theory of mental space (Fauconnier, 1985), image-schemas (Johnson, 1987) and many others. In one of his later works, Fillmore (1986: 49) admits to having given up on maintaining a differentiation between the terms: frame, schema, scene, scripts (a standard event sequence found in a specific context, as described by Schank and Abelson (Schank, Abelson: 1977)), frames, idealized cognitive models, and domains, and so on. He claimed that "rather, all of these reflect different levels of frame knowledge" (Fillmore 1985: 223).

At the same time, Eleanor Rosch with her colleagues presented a pioneering work on the principles of categorization, casting doubt on the classical view of categorization, where belonging to a certain category is conditioned by a set of prerequisites, and category membership is based on an "all-or-nothing" principle. The findings of Rosch and her team suggested that not all members of a category enjoyed "equality" in the category; thus, some members are judged as better examples, taking central positions in the category, while others are at its periphery and assessed as worse examples. A vast amount of experimental work was carried out to support the categorization system presented in the prototype theory (Rosch: 1973, 1977, 1978).

In 1972 Leonard Talmy finished his dissertation and started to introduce the principles of Gestalt psychology into linguistics. As one of the founders of Cognitive Linguistics, Talmy defined his own stance on linguistics, establishing what later became known as Cognitive Semantics. This research was focused on the conceptual structures underlying lexical meaning.

Adopting some of Talmy's assumptions on Gestalt psychology, especially the concepts of figures and ground, Ronald W. Langacker began work on his own theory of conceptual profiling, which became the basis for further cognitive grammar. The research began in 1976 and "the basic framework of the theory extended for over a quarter of a century" (Langacker: 2008). Throughout these years, this framework of linguistic analysis focused on the cognitive mechanisms underlying the formation and use of symbolic units of different degrees of complexity. These units consolidated properties of sound (phonological representation), meaning (semantic representation), and grammar within a single representation 
(Evans: 2006). Thus, the approach represents an apparent deviation from many previously widely shared ideas in linguistics, in direct contrast with the view that syntax, semantics and pragmatics were largely independent of each other.

Starting from the 1980s and onward, we can trace the steady expansion and proliferation of the cognitive linguistic enterprise. One of the most fundamental contributions was that of Ronald W. Langacker, whose take on cognitive grammar began to take the shape of a distinct language model, laid out in two volumes of Foundations of Cognitive Grammar (Langacker: 1987, 1991).

Another key figure in the development of Cognitive Linguistics is George Lakoff and his theory of the conceptual metaphor (Lakoff: 1993; Lakoff, Johnson: 1980, 1993, 1999). In his studies, metaphor was not perceived as merely a stylistic device or figure of speech, but rather an inseparable element of our everyday thoughts and actions. In 1979, Lakoff started cooperation with the philosopher Mark Johnson, and soon the main postulates of the Conceptual Metaphor Theory appeared in their seminal book Metaphors We Live By in 1980.

As the theory matured, a new prominent approach to language study began to emerge in the form of the conceptual mapping theory. Gilles Faulconnier, continuing the study of conceptual metaphors, described one of the most specific and fundamental features of the metaphor. He postulated that the conceptual mechanisms underlying metaphors include not only activation of two domains (source and target), but also a crossspace mapping - a far more complicated process underlying thought and language organization, and the construction of meanings of everyday life. The study was pursued in the 1990s in cooperation with Mark Turner, bringing revolutionary ideas within mental spaces and blending theories.

The 1990s symbolize another landmark for Cognitive Linguistics as the approach became ingrained into mainstream linguistic studies as opposed to a fringe movement. The biannual International Cognitive Linguistics Conference, debuting in Duisburg in 1989, became - and still is a regular venue for cognitive linguists from all over the world, with a constantly growing proliferation of research and publications in the area. The most distinguished linguists are invited to take part in the conference and submit their papers to the ICLA journal Cognitive Linguistics. A few years later (2003), a new journal, Annual of Cognitive Linguistics, was published 
by the John Benjamins Publishing Company under the auspices of the Spanish Cognitive Linguistics Association.

Having its origin as a sharp reaction to the Chomskyan approach to language study, Cognitive Linguistics developed into independent linguistic research with a shared outlook on the cognitive nature of language, though it still represents a cluster of approaches unified by common principles, rather than a unified theory. Today, the most active areas in this field of theoretical linguistic research include conceptual categorization, radial network, conceptual structures, mental spaces, conceptual integration and blending, conceptual metaphor, and metonymy, among others. Moreover the ideas which go under the name of Cognitive Linguistics have their application far beyond language study.

One of the key components of Cognitive Linguistics today is generalization. In assessing this aspect, linguists are searching for the common principles of how we organize our knowledge and experience of the world. An important assumption, made earlier in the experimental studies of Eleonor Rosch, is that categorization is not criterial, as it had been considered in previous objective-oriented theories. It discards the "all-or-nothing" principle, meaning that a member of a category does not need to display some obligatory set of features to be included into the category. Instead, group representatives may have more or less salient features determining their belonging to this group. Group members do not enjoy equality in their position in the group, being either central or peripheral members of this category (ex. Rosch's classic example of members of the BIRD category). Moreover, the degree of centrality is not a fixed notion, but rather depends on our interaction with a particular category at a certain period of time in a certain environment. For example, a bowl becomes central in the CUP category (instead of a teacup, which is more central and expected) when we are thinking about a container for soup. This categorization in Cognitive Linguistics is characterized by fuzziness (Labov: 1973), not only in terms of the centrality that category members exhibit, but also in the boundaries between neighbouring categories. It applies to cases when a member of one category can transition into a neighbouring one.

Principles of conceptual categorization in Cognitive Linguistics are currently applied not only to physical objects, animals, or human beings, but also to broader linguistic categories: morphology, syntax, phonology. The need to explain the nature of the conceptual organization of 
our thoughts behind the meaning conveyed by language and to build a complete conceptual structure has always been at the centre of Cognitive Linguistics studies. This has led to a variety of suggestions for the numerous organized packages of knowledge: frames, scenes, domains, image-schemas, idealised cognitive models, and others.

The first type of cognitive structure to be introduced, the frame, was briefly discussed above in the Frame Semantics approach to Cognitive Linguistics. A frame is a knowledge structure evoked by a lexical unit or grammatical construction which shapes our understanding of a text or conversation. The background knowledge assigned to frames is often so thoroughly "over-learned" that considerable cognitive effort is sometimes required to bring it to consciousness (Fillmore, Baker: 2009, 318). Much earlier, Witttgenstein made a similar observation describing the natural history of human beings, stating that "the aspects of things that are most important for us are hidden because of their familiarity (one is unable to notice something - because it is always before one's eyes)" (Wittgenstein: 1953). The same can be applied to the knowledge evoked by words we hear. "The words we utter we scarcely ever hear. But familiarity in this case should not obscure the importance of the insight" (Chomsky: 2006). As an example of such hidden knowledge, Fillmore describes a process of understanding the word Tuesday. It is impossible to understand the meaning of this word without knowing the established cycle of seven days, how time is reckoned in Western cultures. But this background conceptualization is called on every time the word is used.

Around the same time, Fillmore introduced the "scene-and-frames" paradigm. He writes: "I use the word scene in a maximally general sense, including not only scenes, but also familiar kinds of interpersonal transactions, standard scenarios by the culture, institutional structures, inactive experiences, body image" (Fillmore: 1975). The notion was later in some ways incorporated into the theoretical construct of "domains".

In many contexts, the terms 'frame' and 'domain' are used interchangeably. But there are two fields in Cognitive Linguistics which mainly rely on this knowledge structure. These are the conceptual metaphor theory (Lakoff and Johnson: 1980, 2nd ed. 2003) and Cognitive Grammar (Langacker: 1987, 1991, 2008).

In the conceptual metaphor theory, the notion of domain is employed to describe the process of mapping the underlying conceptual metaphor. Metaphor is understood as the mapping of two "domains of experience": 
from a source domain to a target domain. But what exactly replaces domains has not been expressly stated apart from one distinct feature ascribed to domains: concreteness/abstractness.

Another approach to this knowledge structure was proposed by Langacker as one of the central components in his Cognitive Grammar. Unlike the previous theory, Cognitive Grammar treated the notion of domains more explicitly. In Langacker's understanding, domains, much as frames in Fillmore's Frame Semantics, are based on two major assumptions. First, these knowledge structures are grounded in encyclopaedic knowledge, and, second, the meaning encoded in a lexical unit is not autonomous from the larger cognitive structures evoked by the meaning. Thus, linguistic meaning involves "conceptual content and the construal imposed on the content" (Langacker: 2008). However, the distinction between content and construal is not made absolute. And, as Langacker puts it, "to have a uniform way of referring to content, the term domain is adopted in Cognitive Grammar" (Langacker: 2008). The term is rather broadly interpreted covering many conceptual entities: mental experiences, any realm of experience, concepts, and representational spaces. Though we can see that both theories have a lot in common, the theory of domains added a few significant aspects to Frame Semantics: types of domains, the hierarchical structure of domains (levels of conceptual organization), and a domain matrix.

The development of the image-schema approach is closely associated with the embodied cognition thesis proposed by John Lakoff and Mark Johnson (1980). They rejected the assumption of body and mind dualism when cognitive processes can be studied autonomously from body experience. On the contrary, they claim that the human body and experience are central to the human mind, and that cognition - and, hence, language - cannot be studied in isolation from the human body itself.

Johnson, in his The Body in the Mind: The Bodily Basis of Meaning, Imagination, and Reason (Johnson: 1987), introduces the notion of imageschema to describe the pre-conceptual structure of our experience that gives rise to conceptual structure. "Image schemas are relatively simple structures that constantly recur in our everyday bodily experience: $\mathrm{CON}$ TAINERS, PATHS, LINKS, FORCES, BALANCE, and in various orientations and relations: UP-DOWN, FRONTBACK, PART-WHOLE, CENTERPERIPHERY, etc." (Lakoff: 1987). Thus image-schemas emerge from perception experience, interaction with the world "chiefly at the level of our 
bodily movements through space, our manipulations of objects, and our perceptual interactions" (Johnson: 1987).

Image-schemas, like frames, are among the structuring principles of Idealized Cognitive Models (ICM) - another conceptual structure proposed by Lakoff (Lakoff: 1987). The theory of ICMs was obviously inspired by Rosch's prototype theory, where the prototype effect is a by-product of the organization of our knowledge by means of ICMs. In other words, ICMs guide cognitive processes of categorization. ICMs represent an idealized version of the world that simply does not include all possible real-world experiences. Idealized models do not fit the world very precisely. "It is oversimplified in its background assumptions" (Lakoff: 1987). Lakoff takes a classic example described by Fillmore (Fillmore: 1982) to explain the essence of ICM: the category defined by the English word bachelor. "Bachelor is defined with respect to an ICM in which there is a human society with (a typically monogamous) marriage, and a typical marriageable age" (Lakoff: 1987). This conceptual model says nothing about such categories as priests, homosexuality, long-term unmarried couples, or religions which accept polygamy. It is simply an unmarried adult male.

The work on ICMs laid the groundwork for further investigations in cognitive linguistics, extending to such generalizations as radial and schematic networks. The model was pioneered by Claudia Brugman and George Lakoff (1988). The main assumptions were proposed using an example analysis of the preposition over in "Cognitive topology and lexical networks" (1988). According to the authors, a radial category was another source of prototype effect with graded centrality. Word meanings are claimed to be stored within complex structured categories with less central members understood as variants of more central members. The meaning in this model also extended from a "direct" one to metaphorical. This approach had a considerable influence on further studies of language ambiguity (mainly polysemy) from a Cognitive Linguistics perspective.

George Lakoff was also among those who introduced the Conceptual Metaphor Theory (CMT) - a fundamental premise in Cognitive Linguistics. The foundations of CMT were presented in three cornerstone publications: Metaphors We Live By (Lakoff, Johnson: 1980), The Contemporary Theory of Metaphor (Lakoff: 1993), and Philosophy in the Flesh (Lakoff, Johnson: 1999). The theory explores metaphors as "fundamental" to our thoughts, not just a mere stylistic linguistic device. Lakoff and Johnson, 
thus, argue for relationships between metaphor and human cognition: "...metaphor is pervasive in everyday life, not just in language but in thought and action. Our ordinary conceptual system, in terms of which we both think and act, is fundamentally metaphorical in nature" (Lakoff, Johnson: 1980).

According to this approach, the mechanism of conceptual structuring is based upon mapping between two domains: from a target to a source domain. Lakoff claims that this process is tightly structured and consists of a number of distinct correspondences. As mentioned above, the structure of domains was not explained explicitly within the theory. However, according to the approach, source domains tend to be concrete and are systematically used to structure more abstract target domains by means of mapping. This metaphorical mapping is due to our pre-conceived embodied experience where "STATES ARE LOCATIONS, CHANGE IS MOTION, CAUSES ARE FORCES, PURPOSES ARE DESTINATIONS, MEANS ARE PATHS TO DESTINATIONS" (Lakoff, Johnson: 1980), etc.

The next fundamental theory within the Cognitive Linguistic approach to meaning construction is the theory of Mental Spaces developed by Gilles Fauconnier in two now legendary books: Mental Spaces first published in 1985, and later Mapping in Thought and Language published in 1997. In cooperation with Mark Turner, the theory was then extended to a conceptual blending theory.

One of the main tenets of the theory is that, to a great extent, the process of meaning construction occurs behind the scenes and is thus largely unseen. Linguistic expressions only give us clues or prompts for highly complex conceptual cognitive constructions, which build the meaning "above language" on the ground of encyclopaedic knowledge. These unseen processes stand for a dynamic "back-stage cognition" - what is happening "behind the scenes, in the cognitive background of everyday speaking and common-sense reasoning" (Fauconnier: 1994). Fauconnier claims that "not only are we not aware of the constructions we perform (...), but we do not suspect the extent to which vast amounts of prestructured knowledge, selected implicitly by context, are necessary to form any interpretation of anything. We notice only the tip of the iceberg - the words".

The Mental Space Theory suggests a model for these hidden processes of constructing meaning with corresponding mental constructs mental spaces - dynamic, on-line "conceptual packets" that "prolifer- 
ate when we think and talk" (Fauconnier: 1997) for the purpose of specific ongoing understanding. Thus, the process of meaning-construction is always context-bound. Since mental spaces are constructed on-line and connected by various types of relations, they result in unique conceptual structures with the potential of unlimited meanings. Fauconnier assumes that all spaces are entirely distinct, that is, that they have no elements in common (Fauconnier: 1994).

The main distinction between mental space and the other conceptual structures presented above is that the latter are relatively stable, preexisting knowledge structures, while the former are dynamic temporary structures created as discourse progresses. Thus, mental spaces operate in working memory; they are constructed, adjusted, and modified as discourse unfolds. But once the elements and relations of a mental space are settled, it activates long-term conceptual structure "frames". This activation is performed in a variety of ways for many different purposes depending on the context.

The Mental Space Theory and Conceptual Metaphor Theory contributed significantly to the formation of a new approach within Cognitive Linguistics - Conceptual Blending or Conceptual Integration Theory. The central structural elements of the blending theory are closely related to the Mental Space Theory, which are mental spaces. The meaning construction process is also viewed as dynamic and context dependent. From this perspective, conceptual integration is an extension of Fauconnier's theory on mental spaces. Mark Turner, in his turn, introduced an approach developed on his studies of metaphor in literary language.

The process of conceptual blending starts with the building of an integration network first between two "input spaces" by means of cross-space mapping (the mechanism inherited from a Conceptual Metaphor Theory). Common elements of input spaces are then mapped into a "generic" space. And finally an emergent structure appears - a blend. A blend is not a simple combination of organizations borrowed from two input mental spaces. Instead, it is a new structure with additional information belonging to neither of the inputs with new relations between the structural elements and its own emergent logic.

The theory was initially developed to explore the role of language in a complex meaning- construction process in metaphors, but, later, conceptual integration was seen as "the key mechanism in facilitating the 
development of advanced human behaviours that rely on complex abilities" (Fauconnier, Turner: 2002). Nowadays, this process is viewed as a central and basic operation to the way we think.

This has been a very brief overview of the most prominent landmarks and theories in the history of the formation of Cognitive Linguistics and its development. The most recent research shows that cognitive analysis is widely applied not only to semantical and grammatical phenomena, but also to other language levels. The development of a cognitive view on phonology goes back to the assumptions of Baudouin de Courtenay, who argued that phonemes were mental images of sounds that speakers systematically deformed in the ongoing process of speech according to "physiophonetic" principles that were universally determined by the nature of the speech production and perception apparatus (Baudouin de Courtenay: [1895] 1972). The modern cognitive view on phonology describes it as a representation of our knowledge of bodily experience. Fundamental properties of a sound system are understood as cognitive representations underlying phonological representations. (Nathan, 2008).

Cognitive linguistics has also made a significant contribution to studies in the field of morphology. Based on Langacker's axiom on the centrality of meaning, the word-formation process is treated as meaningful: the concepts expressed by word-formation items and their constituents (whether they enjoy the status of morphemes or not), the structural patterns underlying derivatives and the restrictions imposed on them, and finally the processual aspects of word-formation (such as lexicalization) (Ungerer: 2007). Linguists employ theories of schemas, conceptual blending, radial categories (including metonymic and metaphorical extensions) in the field of inflectional morphology, productivity, and all types of wordformation patterns.

In recent years, as well as developing the field of linguistics itself, Cognitive Linguistics has been successfully applied to a range of different areas including language teaching, language acquisition, translation, intercultural communication, literary criticism, literary and poetic sociolinguistics, philosophy, mathematics, political discourse, as well as in the design of technology, among many others.

Cognitive Linguistics, as we see in this brief historical overview, is incredibly diverse in its theories and approaches to language studies. And it has so much more to offer on other theoretical concerns and assump- 
tions not even touched upon in this study due to its limited capacity. It provides a common principle that links a variety of ideas and assumption where linguistics is viewed not only as the study of mere linguistic forms, but of nature and structure, and the patterns of human thought reflected by these forms.

\section{REFERENCES}

Baudouin de Courtenay J., [1895] 1972, An attempt at a theory of phonetic alternations, in: A Baudouin de Courtenay anthology: The beginnings of structural linguistics, ed. and trans. E. Stankiewicz, Bloomington: Indiana University Press, pp. 144-213.

Brugman C, Lakoff G., 1988, Cognitive topology and lexical networks, in: Lexical Ambiguity Resolution: Perspectives from Psycholinguistics, Neuropsychology, and Artificial Intelligence, eds. L. S., Garrison, W. Cottrell, and M. K. Tanenhaus, San Mateo, CA: Morgan Kaufmann, pp. 477-508.

Chomsky N., 2006, Language and Mind. $3^{\text {rd }}$ edition, Cambridge: Cambridge University Press.

Evans Vyvyan, 2019, Cognitive Linguistics. A complete Guide. $2^{\text {nd }}$ edition, Edinburgh: Edinburgh University Press.

Fauconnier G., 1994, Mental Spaces: Aspects of Meaning Construction in Natural Language, Cambridge: Cambridge Univerity Press.

Fauconnier G., 1997, Mappings in Thought and Language. Cambridge: Cambridge University Press.

Fauconnier G., Turner M., 2002, The Way We Think: Conceptual Blending and the Mind's Hidden Complexities. New York: Basic Books.

Fillmore C., 1975, An alternative to checklist theories of meaning, in: Proceedings of the First Annual Meeting of the Berkeley Linguistics Society. Amsterdam: North Holland, pp. 123-31.

Fillmore C., 1977, Scenes-and-frames semantics, in: Linguistic Structures Processing, eds. A. Zampolli, Amsterdam: North Holland, pp. 55-82.

Fillmore C., 1982, Frame semantics, in: Linguistics in the Morning Calm, ed. Linguistic Society of Korea, Seoul: Hanshin Publishing, pp. 111-37.

Fillmore C., 1985 Frames and the semantics of understanding, in: Quaderni di Semantica, ed. F. Benozzo, Vol. 6, Società editrice il Mulino, pp. 222-254.

Fillmore C., Atkins B.T., 1992, Toward a frame-based lexicon: the semantics of RISK and its neighbors, in: Frames, Fields and Contrasts, eds. A. Lehrer, E. F. Kittay, Hillsdale, NJ: Lawrence Erlbaum, pp. 75-102.

Fillmore C., Baker C., 2009, A frame approach to semantic analysis, in: The Oxford Handbook of Linguistic Analysis, eds. B. Heine, H. Narrog, Oxford: Oxford University Press, pp. 313-344. 
Johnson M., 1987, The Body in the Mind: The Bodily Basis of Meaning, Imagination, and Reason, Chicago: University of Chicago Press.

Johnson M., Lakoff J., 1999, Why cognitive linguistics requires embodied realism, in: Cognitive Linguistics 13-3, (2002), ed. Dagmar Divjak, Berlin: Walter de Gruyter GmbH. \& Co., pp. 245-263.

Lavov W.,1973, The boundaries of words and their meaning, in: New ways of analyzing variation in English, eds. Baily C.-J. N., Shuy R. W, Washington D.C.: Georgetown University Press, 340-373.

Lakoff G., 1987, Women, Fire, and Dangerous Things. What Categories Reveal about the Mind, London: The University of Chicago Press.

Lakoff G., 1993, The contemporary theory of metaphor, in: Metaphor and Thought, ed. O. Andrew, Cambridge: Cambridge University Press.

Lakoff G., Johnson M, 1980, Metaphors We Live by. Chicago: Chicago University press.

Lakoff G., Johnson M, 1999, Philosophy in the Flesh, New York: Basic Books.

Lakoff G., Brockman J., 2000, A Talk with George Lakoff.

Lakoff G., Johnson M., 2003. Metaphors We live By. $2^{\text {nd }}$ edition with a new afterword. London: The University of Chicago Press.

Langacker W.R., 1987, Foundation of Cognitive Grammar. Volume 1: Theoretical Prerequisites, Stanford: Stanford University Press.

Langacker W. R., 1991, Foundation of Cognitive Grammar. Volume 2: Descriptive Application, Stanford: Stanford University Press.

Langacker W. R., Cognitive Grammar. A Basic Introduction. Oxford: Oxford University Press, 2008.

Lewandpwska-Tomaszczyk B., 2007, Polysemy, Prototypes, and Radial Categories, in: The Oxford handbook of Cognitive Linguistics, ed. Dirk Geeraerts, Oxford: Oxford University Press, pp. 139-169.

Nathan G. S., 2015, Phonology, in: Handbook of Cognitive Linguistics, eds. E. Dąbrowska, D. Divjak, Berlin: Mouton de Gruyter GmbH \& Co, pp. 253273.

Nerlich B., Clarke D.D., 2001, Mind, meaning, and metaphor: the philosophy and psychology of metaphor in nineteenth-century Germany, in: History of the Human Sciences vol. 14, No 2, pp. 39-61

Rosch E., 1973, On the internal structure of perceptual and semantic categories, in: Cognitive development and the acquisition of language, ed. T. E. Moore, London: Academic Press, pp. 111-44.

Rosch E., 1977, Human Categorization, in: Studies in Cross-linguistic Psychology, ed. Warren E., London: Academic Press, pp. 1-49.

Rosch E., 1978, Principles of categorization, in: Cognition and categorization, eds. E. Rosch, B. B. Lloyd, Hillsdale N.J., N.Y.: Lawrence Erlbaum, pp. 27-48. 
Rosch E., Mervis C.B., 1975, Family resemblances: studies in the internal structure of categories, in: Cognitive psychology 7, ed. G.D. Logan, pp. 573-605.

Schank, R. C., Abelson, R. P., 1977, Scripts, plans, goals and understanding: An inquiry into human knowledge structures, Hillsdale N.J.: Lawrence Erlbaum.

Ungerer F., 2007, Word-formation, in: Oxford Handbook on Cognitive Linguistics, eds. D. Geeraerts, H. Cuyckens, Oxford: Oxford University Press, pp. 650675.

Wittgenstein L., 1953, Philosophical Investigations, New York: Oxford University Press.

\begin{abstract}
The article offers a brief overview of the most prominent landmarks in the development of Cognitive Linguistics. It starts with the very inception of the field in the late 70 s as a strong reaction against a doctrine of generative linguistics dominating at that time. Later the paper describes the cornerstone theories which were at the onset of this linguistic enterprise. From the very beginning the movement was rather diverse and still cannot be defined as one unified theory; however, there has always been one common factor in its approaches which is the centrality of meaning in language study. The works of the second wave of cognitive linguists, which are also outlined in the article, focused even more increasingly on cognitive functions providing insights into the nature and organization of human thoughts. Nowadays the postulates of Cognitive Linguistics are applied not only to all levels of language study but extended to other scientific areas.
\end{abstract}

Key words: historical context of cognitive linguistics, developing a cognitive linguistic view, cognitive studies

\title{
JEZZYKOZNAWSTWO KOGNITYWNE - PERSPEKTYWA HISTORYCZNA
}

\section{Streszczenie}

Artykuł przedstawia zwięzły opis najistotniejszych dokonań w rozwoju językoznawstwa kognitywnego, począwszy od powstania tej dziedziny u schyłku lat 70-tych $\mathrm{w}$ odpowiedzi na dominującą $\mathrm{w}$ tamtym okresie doktrynę generatywistyki, poprzez przegląd kluczowych teorii składających się na nowy nurt w lingwistyce. Językoznawstwo kognitywne przedstawione jest jako nauka zróżnicowana od samego zarania i nadal nie dająca sie wpisać w ujednolicone ramy teoretyczne, ale cechująca się istotnym elementem wspólnym dla wszystkich podejść istniejących w jej obrębie, a mianowicie centralnym miejscem znaczenia w badaniu i opisie języka. W dalszej części pracy porusza się tematykę drugiej fali rozwoju nurtu i najważniejszych prac powstałych w efekcie badań prowadzonych w jej ramach i jeszcze bardziej skoncentrowanych na roli funkcji 
poznawczych, dzięki którym uzyskuje się pełniejszy wgląd w strukturę aparatu myślowego człowieka. Postulaty współczesnego językoznawstwa kognitywnego mają zastosowanie nie tylko $\mathrm{w}$ badaniach językowych, lecz także $\mathrm{w}$ wielu innych obszarach nauki.

Słowa kluczowe: kontekst historyczny językoznawstwa kognitywnego, lingwistyka kognitywna, badania kognitywne, nauki poznawcze 